\title{
THE EFFECTS OF STRATEGIC MANAGEMENT PRACTICES ON THE PERFORMANCE OF THE UNIVERSITIES IN TURKEY
}

\author{
*Mehmet BIRINCI \\ **Erol EREN \\ * Istanbul Sabahattin Zaim University, Turkey \\ ** Profesor on strategic management Istanbul, Turkey
}

\begin{abstract}
In the present study strategic management practices of the universities in Turkey were investigated and the effects of these practices on the performance of the universities were analyzed. The research investigated whether strategic management processes were implemented in universities in Turkey or to what extent they were implemented and the effects of these processes on the performance of the universities tested by means of a model which was developed. Concrete suggestions were made depending on the results. In the study, it was concluded that the universities operating in our country did not closely follow the changes and developments mainly about higher education in Turkey and in the world and that they did not pay enough attention to the competitive conditions and use strategic management practice adequately.
\end{abstract}

Key words: Strategy, Strategic Planning, Strategic Management, Strategic Management in Universities, Competition, Universities in Turkey, Institutional Performance.

\section{INTRODUCTION}

In Turkey, as well as in the world, universities which are one of the fundamental institutions of societies, must be restructured in order to go through an important change and transformation process and compete with the leading national and international universities. It is considered that implementation process of the increasing expectations from universities can be made possible by good management of these institutions, and this can be achieved when universities adapt and implement a more professional management style along with the concept of strategic management. In parallel with the changes, transformations and extension in higher education and other fields in the world, the demand for higher education has also increased rapidly in Turkey as well. We can follow now one of these processes in higher education, where Turkey has its place only in terms of extension. The number of universities has reached totally 168 (103 state universities plus 65 foundation (private) universities founded over the last years). Along with this extension, the main reason for the high number of students per lecturer or senior lecturer is that the number of lecturers has not increased enough in number when compared to that of students (Günay, D., Günay, A., 2011). In order to meet ever-increasing expectations and achieve sustainable competitive advantage in Turkey and in the world, universities must implement strategic management models which should be directly related to the concept of quality, human and technological infrastructures and the performance they will show accordingly.

\section{LITERATURE RESEARCH}

\section{Strategic Management}

Over the last years economic and social changes and developments have increased the importance of business management in the social system and a real revolution has been taking place in the field of management (Koçel, 2007). This process went through four different stages until it reached the 
concept of "strategic management", which is frequently used today. These stages are the following: (1) primary financial planning, (2) prediction-based planning, (3) strategic planning (outwardoriented), (4)strategic management (Eren, 2010). Durecker (1973) sees strategic management as a continuous process comprising three factors conflicting with each other (Luhanga, Mkude, Mbwette, Chijoriga and Ngirwa, 2003). Ülgen and Mirze (2010) make a similar definition and state the issues of strategic management have undergone a change over the last fifty years as long term planning, institutional planning, strategic planning and strategic management, respectively. The concept of "Strategic Management for the Future", which has come up in recent years, is a new management technique that examines the development, planning, implementation, monitoring and control of effective strategies for the organizations to reach their goals (Porter L.W. and McKibbin, 1988). According to John M. Bryson, strategic management is "a management technique which shows what an organization does, the reason for its being and its future goals' (Aktan, 2008). Toma (2010) defines strategic management as the formulation, implementation, and evaluation of counter-functional decisions which make it possible for an organization to achieve its goals. Güçlü (2003) expresses the prime task of strategic management by quoting from Peter Drucker's own statement "it is the task of thinking through the mission of the business, that is, of asking the question "What is our business and what should it be?" and this leads to the setting of objectives and the making of today's decisions for tomorrow's results." According to another definition, strategic management involves analyses, decisions and activities an organization undertakes to create competitive advantage and sustain it (Akgemci and Güleş, 2010). What is aimed by strategic management is to consider organizations together with environmental variables and make managerial decisions considering possible environmental changes (Düren, 2000; Ereş, 2004). Strategic management and strategic management process are associated with making decisions about what an organization has to do and where it has to go (Howe, 1993; Ereş, 2004). No doubt that it is necessary to use strategic management process effectively and pay importance to environmental scanning and analyses because a profound environmental analysis is one of the most important factors of a comprehensive decision-making process (Hambrick et al. 1981; Alpkan and Doğan, 2008).

\section{Strategic Planning and Strategic Management in Higher Education Institutions}

The fact that universities are service-oriented requires them to make different planning in their strategic planning than business enterprises do. According to Lerner (1999), business-oriented strategic planning models show differences in terms of time frame, consensus, value system, customers, conditions and organizational structure when compared to university-based strategic planning models (Luhanga et al., 2003). Strategic planning enables to take full advantage of the opportunities for the future of the universities and establish a more appropriate relationship with its important stakeholders out of university (Rowley and Sherman, 2004). Keller (1983), Rowley, Lujan and Dolence (1997) and others insistently suggested that strategic planning in the academy was not different from the one in a business enterprise and emphasized the need for participation. They added the shared governance values to the process and encouraged the strategic planners to draw strategic planning methods in the academy (Sullivan and Richardson, 2011). An academic plan, as suggested by Anketell, "functions primarily for an integrative planning process" and then each of the administrative and academic planners can start to make plans in their own fields of responsibility as their planning processes. Thus, the final plan comes out plausibly and with a well-adapted agreement of both areas (Rowley and Sherman, 2004). The importance of the relationship between strategic planning and evaluation to make the institution efficient has been realized by the administrations of higher education institutions more and more each day (Holloway et al., 2006). The units supporting management and education are increasingly concerned about how to better achieve annual goals and objectives. In addition, these efforts are not always in harmony with the goals and objectives of the strategic planning of an institution (Sullivan and Richardson, 2011). Sullivan and Richardson (2011) and Middaugh (2010) point out "evaluation of management effectiveness is much more difficult than maintaining efficiency of academic units. Today universities are expected to play a leading role in the production and dissemination of information, conduct researches and trainings on the issues that will meet social demands and needs and provide service (Denman,2005: Küçükcan and Gür, 2010). Today, 
offering information produced in universities to the society as a commercial commodity is often argued. However, it is a fact that should not be ignored that most of the production of scientific results is carried out in universities (Bülbül and Özbay, 2011). Globalization and removal of borders between countries led to other and very important reflections in higher education. Emergence of distance education and joint programs, export of higher education services by the countries such as the USA, England and Australia have led to international and intercontinental cooperations among universities (Rehber, 2007). These cooperations and developments indicate how important strategic planning is for universities and therefore it is clear that strategic planning will lead these institutions to a better future by adapting to the environment as well as education policies (Nayeri and Mashhadi and Mohajeri, 2008). During the policy determination process of the countries, commercialization of the researches conducted at universities came up as a primary trigger in national competition (Bülbül and Özbay, 2011). Today, three main parameters - creativity, innovativeness and entrepreneurship - stand out in universities. Therefore, the roles of universities are redefined and new university concepts and models are emphasized (Duderstadt, 2000; Duderstadt and Wulf, 2002; Küçükcan and Gür, 2010). According to Wissema (2006/2009), there is now a shift to the concept of the third generation university in the world. He states "the third generation university model gives more freedom to universities in their options and we think that it is compulsory to start using this model." Accordingly, the Council of Higher Education (YOK), in the Turkish Higher Education Strategy Report (2007), stresses on the increasing expectations of various social groups from universities during the transition process to knowledge-based society and economy. Universities have to act in a way to fulfill the expectations considering the concept of strategic management.

\section{Strategic Planning and Strategic Management in the Turkish Higher Education}

The Turkish higher education system shows great differences regarding its establishment dates and number of students. The system has a multicultural and complex structure incorporating a large number of higher education institutions such as state and foundation universities the numbers of which increase day by day, open education, vocational high schools, distance education, graduate (doctoral and master's) programs (Şenses, 2007). There have been very serious problems with the strategic planning practices in educational institutions. It is seen that there is not enough information and attention about the acquisitions of the implementation of strategic planning and it is considered as the biggest drawback. Strategic planning stages in universities in Turkey are implemented in various ways, but strategic management processes are not included. However, universities have to renew themselves in line with the developments in the world and keep up with the changes. Günay (2007) says the following on the changes in the higher education area: "In today's world, technology, globalization and competition which are called as the three unholy forces of change affect all areas. These dynamics cause a change in higher education, challenging national borders, respectable traditions, and recognitions unquestioned before. Universities turn their attention to the external world more than ever before."

In parallel with the extension in higher education in the world, the demand for higher education has also increased rapidly in Turkey as well. As a consequence, the number of universities has reached totally 168 as 103 state universities together with the ones founded over the last years and 65 foundation universities. This extension in universities naturally caused the number of students to increase; however, the number of academic staff fell behind. Universities developed quantitatively, but unfortunately they did not fulfill the expectations. The problems arising from the extension made university administrations more complex. Noticing the problem, mainly the government and higher education planners saw that the need to keep up with contemporary changes and developments was inevitable in university administrations, so a strategic plan which was officially defined in the Law on "Public Financial Management and Control" numbered 5018 issued in 2003 and was mandatory to be implemented in the public institutions as of 2006, is defined in the law as follows: "it expresses a plan consisting medium and long term goals of the public administrations, their objectives and priorities, performance criteria, methods to be used to perform them and allocation of resources." 
Journal of Global Strategic Management | V. 7 | N. 1 | 2013-June | isma.info | 17-33 | DOI: 10.20460/JGSM.2013715673

Based on the law numbered 5018 and within the framework of the regulation based on this law, A Strategic Planning Guide was prepared by the Presidency of the Council of Higher Education, and ADEK (Academic Evaluation and Quality Development Committee) was founded. In the guide which was prepared to guide all higher education institutions, all stages of strategic planning were discussed and it was stated how and through what channels the results of the planning would be released to the public. Moreover, it was stated that only strategic planning was not enough and that internal and external evaluations to be carried out at the end of this process would be examined by the committee (ADEK) and submitted to the presidency of the Council of Higher Education, and higher education institutions were asked to complete these processes. In this context there are some arrangements carried out to prepare a better future for universities: European Quality Assurance System introduced under Bologna process; the law numbered 5018 and relevant regulations; The Regulation on Academic Evaluation and Quality Development in Higher Education Institutions prepared by the Council of Higher Education; Processes of Institutional Evaluation, Periodical Monitoring and Improvement including Strategic planning, Self-evaluation and Environmental Evaluation".

\section{Institutional Performance}

When considered in terms of institutions, performance is defined as "the ability to reach the predetermined goals of an organization by using its resources most effectively" (Daft, 1997; Oyman, 2009), and according to Akal (2005), it is defined as "the evaluation of efforts made to achieve business goals" (p.17). When the relationship between performance and strategic management process is considered, it can be stated that system management is carried out by means of a process comprising the components of data, analysis and action (Oyman, 2009). Strategic management is a dynamic process which plays an effective role in solving performance problems of an organization and in which performance of an organization is constantly evaluated, examined and the stakeholders interact with one another (Cheoul Kang, 2006; Büyük, 2009). Recently the consistency between competition strategy and human resources strategy and its practices and performance has been an important component regarding the success of the business (Wang and Shyu, 2008; Alayoğlu, 2010). Some of the most important early studies focusing on the explanations and researches that can be stated as the relationship between performance and strategy are the ones known as studies on PIMS analysis (Schoeffler et al., 1974) and beer industry (Hatten, Schendel and Cooper, 1978;). Institutional performance management should include the identification of strategic goals by analyzing the current situation of the business enterprise, the formation of plans depending on the goals and the allocation of necessary resources in accordance with the strategic goals in order to achieve them (Akgemci and Güleş, 2010). According to Ischinger (2006), academic differences in higher education institutions pose a problem in terms of developing joint evaluation criteria because basic duties undertaken by higher education institutions can be different, or they can also come from different disciplines. (Rehber, 2007). Several performance-based formulas have been used in almost all European countries for the determination of the resources allocated to higher education institutions. Many countries began to use lump-sum budgets and formulas and they associated allowances to performance. Universities in OECD countries are controlled by means of performance-based budget and quality control systems by the centralized governments (Küçükcan and Gür, 2010). The main purpose of this implementation is to develop opportunities, maintain the difference, provide efficient and effective use of resources, increase and sustain quality and provide consistency in the budget (Zaharia, 2002; Küçükcan and Gür, 2010).

Many researchers showed that the use of strategic human resources management practices has a positive relationship with financial and operational performance (Delaney and Huselid, 1996; Benligiray, Geylan and Duman,2010). Institutions should realize the changes happening around them and get important and true information and carry out processes that will be able to manage information in order to successfully deal with the increasing competition (Ndlela and Toit, 2001; İpçioğlu and Erdoğan, 2005). Therefore, higher education institutions should develop a performance management process that can measure and control their institutional performances and the performance of their employees in order to achieve their strategies and vision. The measurement of 
Journal of Global Strategic Management | V. 7 | N. 1 | 2013-June | isma.info | 17-33 | DOI: 10.20460/JGSM.2013715673

institutional performances of universities can be considered as a more important issue in the future and it can be used as a criterion in the determination of resources allocated to universities in Turkey.

\section{Research Method}

The survey method was used as data collection method. A questionnaire is an observation carried out by preparing a list of questions to be read and responded correctly by the respondents (Seyidoğlu, 1995, p.30). A questionnaire was used by using face-to-face interview method particularly in the pilot study since it is known as a data collection method through written communication. In the study conducted later, the questionnaire was administered via an electronic database in order to increase participation, evaluate data more healthily in the SPSS and prevent data loss. SPSS statistics program and AMOS 4.0 (structural equation method) was used to evaluate the data. In order to analyze the relationship between the variables in the research model, exploratory factor analysis, confirmatory factor analysis (structural equation model), correlation analysis and path analysis (structural equation model) were used.

\section{Purpose of the Research}

It is the purpose of the present study to emphasize the importance of "Strategic Management" in universities, reveal what should be done by determining the shortages arising from current practices during the stages of planning, implementation, and control regarding strategic management. The members of the study include academic staff working at state and foundation universities operating in Turkey. The sampling frame of the research comprises 130 universities (89 state and 41 foundation universities). In the study conducted within the scope of the questionnaire, 35.307 lecturers were sent an invitation; 2.916 of the lecturers examined the questionnaire and 890 lecturers completed the questionnaire in full.

\section{Research Hypotheses}

The hypotheses written below were tested within the scope of the research. The hypotheses in which the relationships between external environmental and internal environmental analyses and planning, implementation, control and monitoring of the strategies comprising strategic management process and strategic flexibility will be explained are as follows:

Hypothesis H1 There is a positive relationship between external environmental analysis and planning of strategies.

Hypothesis $\mathrm{H} 2$ There is a positive relationship between external environmental analysis and implementation of strategies.

Hypothesis $\mathrm{H} 3$ There is a positive relationship between external environmental analysis and monitoring and control of strategies.

Hypothesis $\mathrm{H} 4$ There is a positive relationship between external environmental analysis and strategic flexibility.

Hypothesis H5 There is a positive relationship between internal environmental analysis and planning of strategies.

Hypothesis H6 There is a positive relationship between internal environmental analysis and implementation of strategies.

Hypothesis $\mathrm{H} 7$ There is a positive relationship between internal environmental analysis and monitoring and control of strategies.

Hypothesis H8 There is a positive relationship between internal environmental analysis and strategic flexibility.

The hypotheses intended to find out the relationships between planning, implementation, control and strategic flexibility which is expressed as quick adjustment of the institutions to new conditions and institutional performance are developed and stated as follows: 
Journal of Global Strategic Management | V. 7 | N. 1 | 2013-June | isma.info | 17-33 | DOI: 10.20460/JGSM.2013715673

Hypothesis $\mathrm{H} 9$ There is a positive relationship between planning of strategies and institutional performance.

Hypothesis H10 There is a positive relationship between implementation of strategies and institutional performance.

Hypothesis H11 There is a positive relationship between monitoring and control of strategies and institutional performance.

Hypothesis H12 There is a positive relationship between flexibility and institutional performance.

Finally, the hypotheses developed to find out the relationships between internal and external environmental analyses and institutional performance are as follows:

Hypothesis H13 There is a positive relationship between internal environmental analysis and institutional performance.

Hypothesis H14 There is a positive relationship between external environmental analysis and institutional performance.

\section{Data Analysis}

Firstly, demographic characteristics of the participants were investigated and validity and reliability analyses of the scales were conducted before testing the research hypotheses. In order to conduct validity and reliability analyses, firstly, exploratory factor analysis (EFA) was carried out and then it was investigated whether the scales had discriminant and convergent validity by conducting confirmatory factor analysis (CFA). Exploratory factor analysis was carried out by using SPSS. A structural equation model was developed to conduct confirmatory factor analysis and AMOS 4.0 structural equation software was used for it. In order to investigate the relationship between the variables of the research model, the structural equation model was used to see whether the hypotheses were supported by means of correlation analysis and path analysis.

\section{Demographic Characteristics of Participants}

$84,4 \%$ of the respondents work at state universities and $15,6 \%$ work at foundation universities. It is seen that $28 \%$ of those participating in the research are assistant professors. Only a few are associate professors. In addition, 58\% are senior lecturers (full professors, associate professors and assistant professors). Most of the academicians (76\%) completed their doctoral study at a domestic university. The ratio of the participants with a 5 or less years of tenure is $36,5 \%$. 
Table.1. Demographic Characteristics

\begin{tabular}{|c|c|c|c|c|}
\hline & & Frequency & Percent & $\begin{array}{c}\text { Cumulative } \\
\text { Percent }\end{array}$ \\
\hline \multirow{3}{*}{ 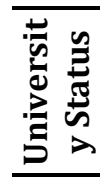 } & State & 751 & 84,4 & 84,4 \\
\hline & Foundation & 139 & 15,6 & 100 \\
\hline & TOTAL & 890 & 100 & \\
\hline \multirow{7}{*}{ 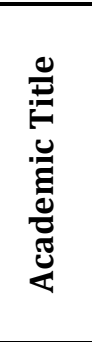 } & Professor & 155 & 17,4 & 17,4 \\
\hline & Associate Professor & 107 & 12,0 & 29,4 \\
\hline & Assistant Professor & 257 & 28,9 & 58,3 \\
\hline & Doctor & 47 & 5,3 & 63,6 \\
\hline & Lecturer & 148 & 16,6 & 80,2 \\
\hline & Research Assistant & 176 & 19,8 & 100 \\
\hline & TOTAL & 890 & 100,0 & \\
\hline \multirow{4}{*}{ 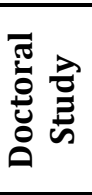 } & Domestic & 676 & 76,0 & 76,0 \\
\hline & Abroad & 74 & 8,3 & 84,3 \\
\hline & Non-Doctoral Education & 140 & 15,7 & 100 \\
\hline & TOTAL & 890 & 100,0 & \\
\hline \multirow{5}{*}{ 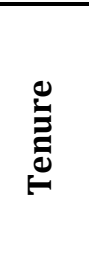 } & $0-5$ years & 325 & 36,5 & 36,5 \\
\hline & $6-10$ years & 177 & 19,9 & 56,4 \\
\hline & $11-15$ years & 167 & 18,8 & 75,2 \\
\hline & Over 16 years & 221 & 24,8 & 100 \\
\hline & TOTAL & 890 & 100 & \\
\hline \multirow{11}{*}{ 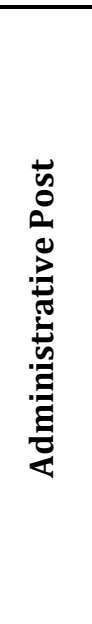 } & None & 583 & 65,5 & 65,5 \\
\hline & President/Vice-President & 11 & 1,2 & 66,7 \\
\hline & Dean/Vice-Dean & 36 & 4,0 & 70,7 \\
\hline & Institute Director/Assistant Director & 15 & 1,8 & 72,5 \\
\hline & School Director/Assistant Director & 16 & 1,8 & 74,3 \\
\hline & Vocational School Director/Assistant Director & 11 & 1,2 & 75,5 \\
\hline & Head/Assistant Head of Department & 147 & 16,5 & 92,0 \\
\hline & Department Head/ABD/Assistant Head & 59 & 6,7 & 98,7 \\
\hline & Director of Continuous Education Center & 4 & 0,4 & 99,1 \\
\hline & Director of Research Center & 8 & 0,9 & 100,0 \\
\hline & TOTAL & 245 & 100 & \\
\hline \multirow{6}{*}{ 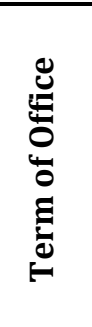 } & No Administrative Post & 583 & 65,5 & 65,5 \\
\hline & $0-3$ years & 190 & 21,3 & 86,8 \\
\hline & $4-8$ years & 72 & 8,1 & 94,9 \\
\hline & $9-12$ years & 20 & 2,3 & 97,2 \\
\hline & Over 13 years & 25 & 2,8 & 100.00 \\
\hline & TOTAL & 245 & 100 & \\
\hline
\end{tabular}




\section{Reliability and Validity Analyses}

Firstly, Kaiser-Meyer-Olkin (KMO) sampling adequacy test and Bartlett's test of sphericity were applied. KMO sampling adequacy value was found to be 0,981 and it was seen to be much more than the suggested 0,50 (Hair, Anderson, Tatham and Black, 1998). Moreover, Bartlett's test of sphericity is tatistically significant at the level of $(\chi 2(1830)=52531,8 ; p<0,01) 1 \%$ ((Hansen and Bush, 1999). Therefore, it was concluded that the sampling was appropriate for the factor analysis. Item total correlation values of the indicators were analyzed and the values were found to be higher than 0,40 . If the correlation value is higher than 0,40 , that indicator is related to the other indicators at least at a medium-range and the best component of the factor (Leech et al., 2005). In addition, communalities are higher than 0,30 and this shows that each of the indicator shares common variance with the other indicators (Field, 2005). Accordingly, in the light of this information, 56 indicators (problems) were determined to be suitable for factor analysis. "Basic Components Analysis" was used together with exploratory factor analysis. 1 indicator was eliminated since it was loaded on more than one factor and factor load was 0.40 or higher (factor load - cross loading in other factors); it was not loaded on a factor and factor load was not equal to 0.50 or higher.

Table.2. Exploratory Factor Analysis Results

\begin{tabular}{|c|c|c|c|c|c|c|c|c|c|}
\hline \multirow[b]{2}{*}{ Statements } & \multicolumn{7}{|c|}{ Components } & \multirow[b]{2}{*}{ 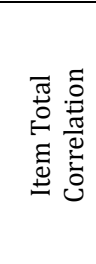 } & \multirow[b]{2}{*}{ 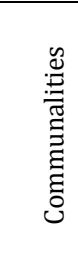 } \\
\hline &  & 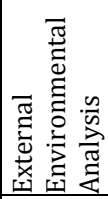 & 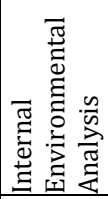 & 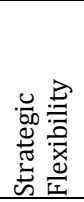 & 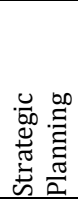 & 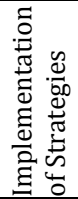 & 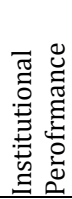 & & \\
\hline C2_r8 & 0,767 & & & & & & & 0778 & 0806 \\
\hline C2_r7 & 0,766 & & & & & & & 0 & 0,000 \\
\hline C2_r3 & 0,763 & & & & & & & & \\
\hline C2_r4 & 0760 & & & & & & & 0,795 & 0,813 \\
\hline & & & & & & & & 0,802 & 0,777 \\
\hline C2_r11 & 0,757 & & & & & & & 0,816 & 0,824 \\
\hline $\mathrm{C} 2$ r 9 & 0,751 & & & & & & & 0,79 & 0,798 \\
\hline C2_r12 & 0,748 & & & & & & & 0802 & 082 \\
\hline C2_r6 & 0,747 & & & & & & & 0826 & 0781 \\
\hline C2_r10 & 0,741 & & & & & & & 0011 & 0700 \\
\hline C2_r2 & 0,722 & & & & & & & 0801 & נוניוס \\
\hline C2_r5 & 0,717 & & & & & & & Q 7001 & ב \\
\hline C2_r1 & 0,697 & & & & & & & 0 & $0,7 \mathrm{TJ}$ \\
\hline C2_r14 & 0,694 & & & & & & & & \\
\hline & & & & & & & & 0,758 & 0,711 \\
\hline CL_T & 0,300 & & & & & & & 0,699 & 0,599 \\
\hline B_r3 & & 0,792 & & & & & & 0,618 & 0,736 \\
\hline B_r1 & & 0,790 & & & & & & 0.647 & 0759 \\
\hline B_r2 & & 0,774 & & & & & & 062 & 0717 \\
\hline B_r7 & & 0,751 & & & & & & 061 & 770 \\
\hline B_r4 & & 0,728 & & & & & & & \\
\hline B_r8 & & 0718 & & & & & & 0,592 & 0,639 \\
\hline & & & & & & & & 0,662 & 0,688 \\
\hline B_r5 & & 0,714 & & & & & & 0,659 & 0,696 \\
\hline B_r9 & & 0,683 & & & & & & 0,668 & 0,649 \\
\hline B_r6 & & 0,646 & & & & & & & \\
\hline
\end{tabular}




\begin{tabular}{|c|c|c|c|c|c|c|c|c|c|}
\hline $\begin{array}{l}\text { B1_r5 } \\
\text { B1_r7 } \\
\text { B1_r6 } \\
\text { B1_r2 } \\
\text { B1_r8 } \\
\text { B1_r3 } \\
\text { B1_r4 } \\
\text { B1_r1 }\end{array}$ & & & $\begin{array}{l}0,702 \\
0,683 \\
0,662 \\
0,649 \\
0,641 \\
0,620 \\
0,602 \\
0,579\end{array}$ & & & & & $\begin{array}{l}0,625 \\
0,672 \\
0,677 \\
0,603 \\
0,695 \\
0,578 \\
0,728 \\
0,7 \\
\end{array}$ & $\begin{array}{l}0,765 \\
0,71 \\
0,734 \\
0,719 \\
0,691 \\
0,652 \\
0,621 \\
0,618 \\
\end{array}$ \\
\hline $\begin{array}{l}\text { C3_r2 } \\
\text { C3_r6 } \\
\text { C3_r4 } \\
\text { C3_r3 } \\
\text { C3_r5 } \\
\text { C3_r1 }\end{array}$ & & & & $\begin{array}{l}0,816 \\
0,801 \\
0,786 \\
0,782 \\
0,773 \\
0,726\end{array}$ & & & & $\begin{array}{l}0,719 \\
0,74 \\
0,695 \\
0,644 \\
0,713 \\
0,696 \\
\end{array}$ & $\begin{array}{l}0,828 \\
0,851 \\
0,834 \\
0,761 \\
0,836 \\
0,694 \\
\end{array}$ \\
\hline $\begin{array}{l}\text { C_r1 } \\
\text { C_r2 } \\
\text { C_r3 } \\
\text { C_r4 } \\
\text { C_r5 } \\
\text { C_r6 } \\
\text { C1_r4 } \\
\text { C1_r6 } \\
\text { C1_r7 } \\
\text { C1_r5 } \\
\text { C1_r3 } \\
\text { C1_r2 } \\
\text { C1_r1 }\end{array}$ & & & & & $\begin{array}{l}0,696 \\
0,668 \\
0,599 \\
0,599 \\
0,565 \\
0,531\end{array}$ & $\begin{array}{l}0,648 \\
0,640 \\
0,630 \\
0,629 \\
0,597 \\
0,585 \\
0,515\end{array}$ & & $\begin{array}{l}0,792 \\
0,777 \\
0,791 \\
0,802 \\
0,784 \\
0,781 \\
0,541 \\
0,591 \\
0,484 \\
0,675 \\
0,517 \\
0,735 \\
0,732\end{array}$ & $\begin{array}{l}0,745 \\
0,791 \\
0,769 \\
0,795 \\
0,704 \\
0,722 \\
0,853 \\
0,826 \\
0,853 \\
0,841 \\
0,812 \\
0,782 \\
0,755\end{array}$ \\
\hline $\begin{array}{l}\text { D_r2 } \\
\text { D_r1 } \\
\text { D_r5 } \\
\text { D_r3 } \\
\text { D_r4 }\end{array}$ & & & & & & & $\begin{array}{l}0,757 \\
0,716 \\
0,670 \\
0,662 \\
0,660\end{array}$ & $\begin{array}{l}0,697 \\
0,74 \\
0,752 \\
0,653 \\
0,726\end{array}$ & $\begin{array}{l}0,721 \\
0,701 \\
0,571 \\
0,578 \\
0,732\end{array}$ \\
\hline Eigen values & 29,75 & 3,36 & 2,56 & 1,84 & 1,54 & 1,3 & 1,08 & & \\
\hline $\begin{array}{l}\text { Explained variance } \\
(\%)\end{array}$ & 53,14 & 6 & 4,58 & 3,29 & 2,75 & 2,33 & 1,94 & & \\
\hline
\end{tabular}

The results of the factor analysis (factor loads, total explained variance, item total correlation and communalities) are indicated in Table 2. As seen in Table 2, indicators form scales that are suitable. Moreover, since all factor loads are higher than 0.50 , construct validity is available. In addition, the data set was subject to confirmatory factor analysis in order to investigate the validity of the scales in detail. "Confirmatory factor analysis" was conducted by using AMOS structural equation model software. In the solution obtained by using maximum likelihood method, 55 indicators are seen to be loaded to the related factors. This confirms the unidimensionality of the concepts and presents strong empirical evidence about the validity of the scales (Anderson and Gerbing, 1988). It is seen that there is convergent validity because $t$ test values (critical ratio) of the factor loads are high (higher than 2) (Akgün, Byrne, Lynn and Keskin, 2007). If all factor loads are at least two times more than their own 
Journal of Global Strategic Management | V. 7 | N. 1 | 2013-June | isma.info | 17-33 | DOI: 10.20460/JGSM.2013715673 standard errors, it is accepted that the scale shows convergent validity. As seen in Table 3, the lowest $\mathrm{t}$ test value (critical ratio) is 19,754 and this value is much higher than 2 . This finding shows that indicators measure the concept effectively (Anderson and Gerbing, 1988). The $\chi 2(7)$ value of the measurement is obtained as 21,04. Moreover, $\chi 2 / \mathrm{df}$ (degree of freedom) is equal to 3,006. All in all, measurement model and data are seen to be quite fit with each other. According to the Fit indexes Comparative Fit Index (CFI) = 0,94, Incremental Fit (IFI) =0,93, Non-normed Fit Index (NNFI) =0,92 and Root Mean Square Error of Approximation (RMSEA) $=0,048$. This indicates that general compliance of the measurement model is good. In the light of all this information, it is concluded that the scales (concepts) have convergent validity.

Table.3. Confirmatory Factor Analysis Results

\begin{tabular}{|c|c|c|c|c|}
\hline $\begin{array}{c}\text { Concept } \\
\text { (Variable) and } \\
\text { Indicators }\end{array}$ & $\begin{array}{l}\text { Non- } \\
\text { Standard } \\
\text { Factor } \\
\text { Loads }\end{array}$ & $\begin{array}{c}\text { Standard } \\
\text { Factor Loads }\end{array}$ & SE & $\begin{array}{l}\mathrm{t} \text {-value } \\
\text { (critical } \\
\text { ratio) }\end{array}$ \\
\hline \multicolumn{5}{|l|}{$\begin{array}{l}\text { External } \\
\text { Environment } \\
\end{array}$} \\
\hline B_r1 & 1,000 & 0,825 & $\_\mathrm{a}$ & _b \\
\hline B_r2 & 0,947 & 0,788 & 0,026 & 36,455 \\
\hline B_r3 & 0,967 & 0,822 & 0,033 & 29,277 \\
\hline B_r4 & 0,882 & 0,765 & 0,033 & 26,352 \\
\hline B_r5 & 0,951 & 0,821 & 0,033 & 29,225 \\
\hline B_r6 & 0,921 & 0,724 & 0,038 & 24,432 \\
\hline B_r7 & 0,974 & 0,839 & 0,032 & 30,201 \\
\hline B_r8 & 0,945 & 0,795 & 0,034 & 27,836 \\
\hline B_r9 & 0,911 & 0,763 & 0,035 & 26,231 \\
\hline \multicolumn{5}{|l|}{$\begin{array}{l}\text { Internal } \\
\text { Environment }\end{array}$} \\
\hline B1_r1 & 1,000 & 0,757 & $\_\mathrm{a}$ & -b \\
\hline B1_r2 & 1,098 & 0,822 & 0,042 & 26,030 \\
\hline B1_r3 & 0,964 & 0,778 & 0,040 & 24,382 \\
\hline B1_r4 & 0,882 & 0,735 & 0,039 & 22,859 \\
\hline B1_r5 & 1,121 & 0,849 & 0,041 & 27,060 \\
\hline B1_r6 & 1,080 & 0,834 & 0,041 & 26,485 \\
\hline B1_r7 & 1,078 & 0,801 & 0,043 & 25,257 \\
\hline B1_r8 & 1,052 & 0,800 & 0,042 & 25,194 \\
\hline \multicolumn{5}{|l|}{ Strategic planning } \\
\hline C_r1 & 1,000 & 0,716 & $\_\mathrm{a}$ & -b \\
\hline C_r2 & 1,031 & 0,789 & 0,033 & 31,458 \\
\hline C_r3 & 1,305 & 0,894 & 0,050 & 26,349 \\
\hline C_r4 & 1,332 & 0,914 & 0,049 & 26,934 \\
\hline C_r5 & 1,228 & 0,846 & 0,049 & 24,908 \\
\hline
\end{tabular}


Journal of Global Strategic Management | V. 7 | N. 1 | 2013-June | isma.info | 17-33 | DOI: 10.20460/JGSM.2013715673

\begin{tabular}{|c|c|c|c|c|}
\hline C_r6 & 1,219 & 0,853 & 0,049 & 25,115 \\
\hline \multicolumn{5}{|c|}{$\begin{array}{l}\text { Implementation of } \\
\text { Strategies }\end{array}$} \\
\hline C1_r1 & 1,000 & 0,838 & $\_\mathrm{a}$ & _b \\
\hline C1_r2 & 1,019 & 0,860 & 0,031 & 32,951 \\
\hline C1_r3 & 1,007 & 0,873 & 0,030 & 33,882 \\
\hline C1_r4 & 1,047 & 0,906 & 0,029 & 36,259 \\
\hline C1_r5 & 1,064 & 0,901 & 0,030 & 35,890 \\
\hline C1_r6 & 1,024 & 0,881 & 0,030 & 34,308 \\
\hline C1_r7 & 1,071 & 0,906 & 0,030 & 36,246 \\
\hline \multicolumn{5}{|c|}{$\begin{array}{l}\text { Control of } \\
\text { Strategies }\end{array}$} \\
\hline C2_r1 & 1,000 & 0,817 & $\_\mathrm{a}$ & _b \\
\hline C2_r2 & 1,049 & 0,861 & 0,028 & 37,527 \\
\hline C2_r3 & 1,078 & 0,875 & 0,033 & 32,729 \\
\hline $\mathrm{C} 2 \_r 4$ & 1,049 & 0,858 & 0,030 & 35,301 \\
\hline C2_r5 & 1,026 & 0,836 & 0,034 & 30,459 \\
\hline C2_r6 & 1,074 & 0,864 & 0,034 & 32,040 \\
\hline C2_r7 & 1,107 & 0,877 & 0,034 & 32,861 \\
\hline C2_r8 & 1,096 & 0,882 & 0,033 & 33,119 \\
\hline $\mathrm{C} 2 \_r 9$ & 1,141 & 0,889 & 0,034 & 33,587 \\
\hline C2_r10 & 1,120 & 0,894 & 0,033 & 33,903 \\
\hline C2_r11 & 1,127 & 0,899 & 0,033 & 34,199 \\
\hline C2_r12 & 1,112 & 0,899 & 0,033 & 34,165 \\
\hline C2_r13 & 0,970 & 0,730 & 0,039 & 25,054 \\
\hline C2_r14 & 1,091 & 0,825 & 0,037 & 29,831 \\
\hline \multicolumn{5}{|c|}{$\begin{array}{l}\text { Strategic } \\
\text { Flexibility } \\
\end{array}$} \\
\hline C3_r1 & 1,000 & 0,745 & $\_\mathrm{a}$ & -b \\
\hline C3_r2 & 1,109 & 0,849 & 0,034 & 32,613 \\
\hline C3_r3 & 1,049 & 0,826 & 0,041 & 25,769 \\
\hline C3_r4 & 1,179 & 0,911 & 0,041 & 28,863 \\
\hline C3_r5 & 1,184 & 0,918 & 0,041 & 29,114 \\
\hline C3_r6 & 1,188 & 0,927 & 0,040 & 29,458 \\
\hline \multicolumn{5}{|c|}{ Performance } \\
\hline D_r1 & 1,000 & 0,792 & $\_\mathrm{a}$ & -b \\
\hline D_r2 & 0,876 & 0,769 & 0,036 & 24,154 \\
\hline D_r3 & 0,898 & 0,690 & 0,042 & 21,244 \\
\hline D_r4 & 0,965 & 0,845 & 0,036 & 26,983 \\
\hline D_r5 & 0,776 & 0,649 & 0,039 & 19,754 \\
\hline
\end{tabular}

The results of the confirmatory factor analysis indicated in Table 3 showed that all concepts were measured in conformity with the theory. It was seen that Composite Reliability- CR coefficients of all 
Journal of Global Strategic Management | V. 7 | N. 1 | 2013-June | isma.info | 17-33 | DOI: 10.20460/JGSM.2013715673 scales (concepts) were well above the suggested threshold value, which was 0,70 , and that Average Variance Extracted-AVE was well-above the suggested threshold value 0,50 (Fornel and Larcker, 1981).

\section{Testing and Results of Hypotheses}

Correlation and structural equation model was used to test the hypotheses. Correlation is a coefficient that shows the strength of a linear relationship between two variables. If the correlation coefficient is statistically significant, it is said that there is a relationship between the two variables. Correlation coefficient takes a value between -1 and +1 ; the higher the absolute value of the correlation is, the stronger the relationship between the variables is (Newbold, 2009). When correlation coefficients indicating linear relationships between the variables are considered, it is seen that there is relationship at a significance level of 0,01 between the variables $(\mathrm{p}<0,01)$ (See Table 4). Structural equation model was used to test the hypotheses. Structural equation model (SEM) is a statistical technique that is used to test the causal relationships between the observed and unobserved (latent) variables. It is a systematic tool used to evaluate the relationships between the variables and test theoretical models particularly in social sciences (such as psychology, sociology, business administration etc).

SEM assumes that there is a causal structure between the set of latent variables and that latent variables can be measured by means of observed variables (Joreskog and Sörbom, 2001). Structural equation modeling contains one or more linear regression equations that describe how exogenous structures are related to endogenous structures. The coefficients are called as path coefficients or mostly regression weights (Reisinger and Turner,1999).

\section{Table.4. Correlation Coefficients and Descriptive Statistics of Variables}

\begin{tabular}{|c|c|c|c|c|c|c|c|c|c|}
\hline Variables & Mean & $\begin{array}{l}\text { Standard } \\
\text { Deviation }\end{array}$ & 1 & 2 & 3 & 4 & 5 & 6 & 7 \\
\hline 1. External Environmental Analysis & 3,30 & 0,90 & 1,00 & & & & & & \\
\hline 2. Internal Environmental Analysis & 3,39 & 0,93 & $0,70^{* *}$ & 1,00 & & & & & \\
\hline 3. Strategic Planning & 3,46 & 0,92 & $0,60^{* *}$ & $0,71^{* *}$ & 1,00 & & & & \\
\hline 4. Implementation of Strategies & 3,20 & 0,95 & $0,59^{* *}$ & $0,72^{* *}$ & $0,76^{* *}$ & 1,00 & & & \\
\hline 5. Control of Strategies & 3,14 & 0,87 & $0,61^{* *}$ & $0,71^{* *}$ & $0,74^{* *}$ & $0,83^{* *}$ & 1,00 & & \\
\hline 6. Strategic Flexibility & 3,20 & 0,93 & $0,49^{* *}$ & $0,56^{* *}$ & $0,56^{* *}$ & $0,59^{* *}$ & $0,65^{* *}$ & 1,00 & \\
\hline 7. Performance & 3,03 & 0,86 & $0,49^{* *}$ & $0,60^{* *}$ & $0,57^{* *}$ & $0,57^{* *}$ & $0,62^{* *}$ & $0,57^{* *}$ & 1.00 \\
\hline \multicolumn{3}{|l|}{ Cronbach's Alpha Reliability coefficient } & 0,94 & 0,93 & 0,91 & 0,96 & 0,98 & 0,95 & 0.87 \\
\hline \multicolumn{3}{|l|}{ Composite Reliability(CR) } & 0,93 & 0,93 & 0,90 & 0,96 & 0,97 & 0,94 & 0.86 \\
\hline \multicolumn{3}{|l|}{ Average Variance Extracted (AVE) } & 0,63 & 0,64 & 0,7 & 0,77 & 0,75 & 0,74 & 0.56 \\
\hline
\end{tabular}

Fit indexes were used to test the fit of the structural equation model. Fit indexes $\chi 2(7)=21,04 ; \chi 2 / \mathrm{df}$ $=3,006$; comparative fit index $(\mathrm{CFI})=.0,94$, incremental fit index $(\mathrm{IFI})=0,93$ and Root Mean Square Error of Approximation (RMSEA) $=0,048$. These results show the fit of the model. H1 research hypothesis was supported as a result of the analyses conducted and it was found out that external environmental analyses conducted at universities affected strategic planning positively $(\beta=0,07$; $p<0,05)$. H2 research hypothesis was not supported by the analyses $(\beta=-0,01 ; p>0,05)$. According to the research results, the hypothesis was rejected; no significant and positive relationship was found between external environmental analysis and implementation of strategies. H3 research hypothesis was developed as "there is a positive relationship between external environmental analysis and monitoring and control of strategies" and tested accordingly. Within the scope of the research, no relationship was found between the external environmental analyses conducted at universities in Turkey and the control of the strategies; therefore, the hypothesis $(\beta=0,02 ; p>0,05)$ was rejected. H4 research hypothesis was rejected as a result of the analyses $(\beta=0,65 ; p>0,05)$, no significant relationship was found between external environmental analysis and strategic flexibility. It is 
Journal of Global Strategic Management | V. 7 | N. 1 | 2013-June | isma.info | 17-33 | DOI: 10.20460/JGSM.2013715673

understood that universities in Turkey conduct external environmental analysis; however, they do not pay much attention to use these analysis results for the implementation, monitoring and control of the strategies and the adaptation to new conditions. The lack of strategic management level, which is the main reason for the problems in universities in Turkey, is clearly seen. External environmental analysis is of primary importance among the environmental analyses constituting the first step of strategic management process. The strengths and weaknesses with the opportunities and threats found out by external and internal environmental analyses and Swot analysis indicate that there is a strong relationship between strategic management process and Swot analysis.

Table.5. Results of the Hypotheses

\begin{tabular}{|l|l|l|l|}
\hline Hypothesis & Relationship & Path Value & Results \\
\hline & Swot analysis --- Strategic Management Process & & \\
\hline H1 & External Environment Analysis--- Strategic Planning & $0,07^{*}$ & Supported \\
\hline H2 & External Environment Analysis--- Strategic Implementation & 0,01 & Not supported \\
\hline H3 & External Environment Analysis--- Strategic Control & $-0,02$ & Not supported \\
\hline H4 & External Environment Analysis--- Strategic Flexibility & 0,065 & Not supported \\
\hline H5 & Internal Environment Analysis--- Strategic Planning & $0,79^{* *}$ & Supported \\
\hline H6 & Internal Environment Analysis--- Strategic Implementation & $0,84^{* *}$ & Supported \\
\hline H7 & Internal Environment Analysis--- Strategic Control & $0,79^{* *}$ & Supported \\
\hline H8 & Internal Environment Analysis--- Strategic Flexibility & $0,60^{* *}$ & Supported \\
\hline & Swot analysis --- Strategic Management Process & & \\
\hline H14 & External Environment Analysis--- Performance & $-0,001$ & Not supported \\
\hline H13 & Internal Environment Analysis--- Performance & $0,28^{*}$ & Supported \\
\hline & Strategic Management Process --- Performance & & \\
\hline H9 & Strategic Planning --- Performance & $0,14^{*}$ & Supported \\
\hline H10 & Strategic Implementation --- Performance & -0.04 & Not supported \\
\hline H11 & Strategic Control --- Performance & $0,23^{* *}$ & Supported \\
\hline H12 & Strategic Flexibility --- Performance & $0,24^{* *}$ & Supported \\
\hline & & $\chi^{2}(7)=21,04$, CFI = 0,94, IFI =0,93 $, \chi^{2} / d f=3,006$, RMSEA $=0,048$ & \\
\hline
\end{tabular}

Path coefficients were standardized. ${ }^{*} p<0,05 ;{ }^{* * *} p<0,01$

H5, H6, H7 and H8 hypotheses stating internal environment analysis affected strategic management process (planning, implementation, evaluation and control and strategic flexibility) were tested by means of the analyses conducted. The research results indicated internal environmental analysis had a positive effect on the planning, implementation and control of strategies and strategic flexibility which is stated as adapting to new situations in universities in Turkey. According to the research results, it was found out that there was a significant and positive relationship between internal environment and planning of strategies $(\beta=0,79 ; \mathrm{p}<0,01)$, implementation of strategies $(\beta=0,84 ; \mathrm{p}<0,01)$, monitoring and control of strategies $(\beta=0,79 ; \mathrm{p}<0,01)$, strategic flexibility $(\beta=0,60 ; \mathrm{p}<0,01)$. The research hypotheses H9, H10, H11 and H12, which were developed to test the effects of strategic management process on performance, were tested through analyses. Accordingly, H9 showed that there was a positive relationship between strategic planning and performance $(\beta=0,14 ; \mathrm{p}<0,05)$; that is, the hypothesis was supported. These results show that strategic planning carried out in universities in Turkey affect performance and that universities consider performance criteria when preparing their strategic plans. However, $\mathrm{H} 10$, which states there is a positive relationship between the implementation of strategies and performance, was rejected $(\beta=-0,04 ; p>0,05)$. It was observed that strategic plans prepared at universities in Turkey were prepared in a way to affect performance positively and that they were not applied adequately during the implementation stage; therefore, they did not provide a positive contribution to performance. The research hypothesis H11 was supported as 
Journal of Global Strategic Management | V. 7 | N. 1 | 2013-June | isma.info | 17-33 | DOI: 10.20460/JGSM.2013715673

a result of the analyses conducted $(\beta=0,23 ; \mathrm{p}<0,01)$. Accordingly, it is possible to say that monitoring and control of strategies have a positive effect on the institutional performance of universities. H12 hypothesis, which states there is a positive relationship between strategic flexibility and institutional performance $(\beta=0,24 ; p<0,01)$ was supported. As a result of this, we can say that strategic flexibility of universities has a positive effect on their performances. The effects of the SWOT analysis conducted as a result of external environmental and internal environmental analyses within the scope of the research on the institutional performance of the universities were investigated. The research hypothesis H13, which was hypothesized accordingly, was supported by the analyses $(\beta=0,28$; $\mathrm{p}<0,01)$. It was observed that works were carried out to see their current situations and what they were capable of within the scope of internal environmental analysis in universities and that these works had a positive effect on the performances of universities. H4 stating that there is a positive relationship between external environmental analysis and institutional performance $(\beta=-0,01 ; p>0,05)$ was not found significant and thus the hypothesis was rejected. According to the result of the research, the reason for the rejection of the hypothesis is considered important since it shows external environmental analysis is not sufficiently paid attention, the changes and developments in Turkey and in the world are not closely followed and the rivals are not taken seriously.

\section{CONCLUSION}

In conclusion, it is seen that particularly external environmental analyses are not carried out adequately in universities in Turkey and thus universities cannot keep up with the developments and transformations in the world mainly regarding higher education. Consequently, universities cannot create a competitive environment within themselves and cannot compete with the world universities and that they exhibit a inward-oriented concept of management. On the other hand, it can be said that universities in Turkey pay more attention to internal environmental analyses, they are positively affected by the planning, implementation and controlling stages of strategic management process and their ability to adapt to changes that are likely to happen in the internal environment is high. Of the stages of strategic management process, planning, controlling and flexibility were seen to have a positive effect on performance, but implementation of strategies was not seen to have an effect on performance. Accordingly, it is possible to say strategies do not have the required effect on performance since they are not implemented sufficiently. In general, it was seen that strategic management process in universities in Turkey was not discussed as a whole and implemented sufficiently and that some of the practices were seen to be irrelevant with one another. For this reason, it is considered that strategic management processes do not provide the required contribution for the success of universities. There is no doubt that the most important result in the present study (what lies behind the poor management of universities) is the lack of strategic management practices. To sum up, it can be said as a result of this research about universities in Turkey that;

-External environmental analyses are not conducted properly,

-Internal environmental analyses are given more importance,

-Universities, in general, exhibit an inward-oriented concept of management,

-Strategic management deal more with the planning stage,

-Universities cannot develop strategies to get competitive advantage,

- The possible external opportunities and threats are not well known,

-Universities cannot properly follow the developments particularly in higher education in Turkey and in the world,

-Since the strategies are not developed properly and fully implemented, no monitoring and evaluation is carried out,

- Since strategic management processes are not discussed as a whole, institutional performance of universities is not up to the mark and it is not positively affected. 


\section{REFERENCES}

Akal, Z. (2005). İsletmelerde Performans Ölçüm ve Denetimi (Performance Measurement and Control in business Enterrises)(6.Edition).Ankara: National Productivity Centre Publications, Publication No: 473.

Akgemci, T., Güleş, H.K. ( 2010). Işsletmelerde Stratejik Yönetim (Strategic Management in Business Enterprises), Istanbul: Gazi Bookstore.

Akgün, A.E., Byrne, J.C., Lynn, G.S., Keskin, H., (2007). New product development in turbulent environments: Impact of improvisation and unlearning on new product performance. Journal of Engineering and Technology Management, 24(3), 203-230.

Aktan,C.C. (2008). Stratejik Yönetim ve Stratejik Planlama (Strategic Management and Strategic Planning). 18.10.2011.http://www.ceis.org.tr/dergiDocs/makale132.pdf.

Alayoğlu, N. (2010). Rekabet Üstünlüğ̈̈ Sağlamada İnsan Kaynaklart ve Rekabet Stratejilerinin Uyumu. (Relationship between Human Resources and Competition Strategies in Providing A Competitive Advantage)Istanbul Ticaret University, Journal of Social Sciences, 9 (17), 27-46, 20.05.2010. http://asosindex.com/journal-article-fulltext?id=8740\&part=1

Alpkan, L., Doğan, T. (2008). Stratejik Planlama Süreci Bileşenlerinin Firma Performansına Etkileri.(The Effects of the Components of Strategic Planning Process on the Company Performance) Kocaeli University Journal of Social Sciences Institute, (16) 2, 21-47. 08.01.2012. Asos Social Sciences index. http://asosindex.com/journal-article-fulltext?id=290\&part=1

Anderson, J.C. and Gerbing, D.W. (1988). Structural equation modeling in practice: A review and recommended two-step approach. Psychological Bulletin, 103, 411-423.

Benligiray, S., Geylan, A., Duman, E. (2010). Insan Kaynakları Yönetiminin Stratejik Olarak Yönlendirilmesinin Finansal Performansı Etkileyip Etkilemediğinin Analizi (An Analysis on the effects of strategic orientation of Human Resources Management on Financial Performance). Anadolu University Journal of Social Sciences,

10 (1), 61-84. 20.05.2012. Asosindex.

Bülbül, Y., Özbay, R.D. (2011). Teknoparklar: Teknolojik Bilginin Ticarileşmesi (Technoparks: Commercialization of Technological Information). İstanbul: Publications of Istanbul Chamber of Commerce, Publication No, 2011-111.

Büyük, K. (2009). Stratejik Performansın Ölçülmesi ve Geliştirilmesinde Kurumsal Başarı Karnesi Ile Faaliyet Raporlarının Karşılaştırılması: Tepebaşı Belediyesi Örneği (Comparison of Corporate Achievement Report and Activity Reports in the Measurement and Development of Strategic Performance: Tepebaşı Municipality ). Doctoral Thesis, Sakarya University, 2009.

Eren, E. (2010). Stratejik Yönetim ve Işsletme Politikası (Strategic Management and Business Policy) ( $8^{\text {th }}$ Edition). İstanbul: Beta Publications.

Ereş, F. (2004). Eğitim Yönetiminde Stratejik Planlama (Strategic Planning in Education Management), Gazi University, Journal of Faculty of Education,15, s.21-29. 01.02.2012. http://www.esef.gazi.edu.tr/html/yayinlar/15_pdf/15-b.pdf

Hansen, E., Bush, R.J. (1999). Understanding Customer Quality Requirements: Model and Application, Industrial Marketing Management. Volume 28, Issue 2, 1999, 119-130.

Field, A.P., (2005). Discovering statistics using SPSS (2nd edition), Sage Publication.

Güçlü, N. (2003). Stratejik Yönetim (Strategic Management), G.Ü. Gazi University, Journal of Faculty of Education, 23 (2), 61-85.

Günay, D. (2007). Yirmibirinci Yüzyılda Üniversite (University in the $21^{\text {st }}$ Century). Değişim Çağında Yükseköğretim (Higher Education in the Transformation Age)(Ist Edition) (pp.77-88). İstanbul : Yaşar Üniversitesi Yayınları. 
Journal of Global Strategic Management | V. 7 | N. 1 | 2013-June | isma.info | 17-33 | DOI: 10.20460/JGSM.2013715673 Günay, D. (2011). Türk Yükseköğretiminin Yeniden Yapılandırılması Bağlamında, Sorunlar, Eğilimler, Illkeler ve Öneriler-I.(Problems, Tendencies, Principles and Suggestions in the context of Restructuring of the Turkish Higher Edcuation-I) Higher Education and Science Journal, 1 (3), pp.113-122. 10.03.2012. http://www.higheredu-sci.org/text.php3?id=1540.

İplikçioğlu,İ. ,Erdoğan, Z. (2005). İşletme Stratejisinin Belirlenmesinde Bilgi Yönetimi Altyapısının Analizi (Analysis of Information Management Infrastructure in the Determination of Business Strategy). Journal of Social Sciences, 2, 89-112. 27.05.2012.

https://www.anadolu.edu.tr/arastirma/hakemli_dergiler/sosyal_bilimler/pdf/2005-2/sos_bil.7.pdf

Koçel, T. (2007). İşletme Yöneticiliği (Business Management) (11 ${ }^{\text {th }}$ Edition). İstanbul: Arıkan Publications,

Küçükcan, T., Gür, B.S. (2010). Türkiye’de Yükseköğretimin Karşılaştırmalı Bir Analizi (A Comparative Analysis of Higher Education in Turkey) ( $2^{\text {nd }}$ Edition). Ankara: Publications of the Foundation for Political, Economic and Social Researches (SETA), Pelin Ofset.

Luhanga, M., Mkude, D.J., Mbwette, T.S.A., Chijoriga, M.M., Ngirwa, C.A. (2003). Strategic Planning And Higher Education Management in Africa:The University of Dar es Salaam Experience. Tanzania: Dar Essalaam University Press.

Nayeri, M. D., Mashhadi M. M. and Mohajeri, K. (2008). Universities Strategic Evaluation Using Balanced Scorecard. World Academy of Science, Engineering and Technology 37.

Newbold, P., Carlson, W., and Thorne, B., (2009). Statistics for Business and Economics, 7. Bask1, Prentice Hall.

Oyman, B. (2009). Stratejik Yönetim Sürecinde Performans Ölçümü ve Dengeli Sonuç Kartı Uygulamast(Perofrmance Measurement and Balanced Scorecard Implementation in Strategic Management Process): Türkiye Cumhuriyeti Merkez Bankası İçin Bir Değerlendirme. Uzmanlık Yeterlilik Tezi (An Evaluation for the Turkish Central Bank. Thesis for Competency in Specialization), 05.06.2012. http://www.tcmb.gov.tr/kutuphane/TURKCE/tezler/sumruoyman.pdf

Porter, L.W., McKibbin, L.E., (1988). Management Education And Development: Drift or Thrust Into The 21st Centruy?. New York: McGraw-Hill, Inc.

Rehber, E. (2007). Dünyada Değişen Yükseköğretim ve Kalite Anlayışı (Concept of Chanigng Higher Education and Quality). Değişim Çağında Yükseköğretim (Higher Education in the Transformation Age) (1 ${ }^{\text {st }}$ Edition) (p.211-243). İstanbul : Yaşar University Publications.

Reisinger, Y., Turner, L. (1999). Structural equation modeling with lisrel: Application in Tourism, Tourism Management, Volume 20, Issue 1, February 1999, Pages 71-88

Rowley, D.J., Sherman, H. (2004). Academic Planning: The Heart and Soul Of The Academic Strategic Plan.University Press of America.

Şenses, F. (2007). Uluslararası Gelişmeler Işı̆̆ında Türkiye Yükseköğretim Sistemi: Temel Eğilimler, Sorunlar, Çelişkiler ve Öneriler (Turkish Higher Education System in the Light of International Developments: Basic Tendencies, Problems, Conflicts and Suggestions). ERC (Economic Research Center) Working Papers in Economics. http://www.erc.metu.edu.tr/menu/series07/0705.pdf

Sullivan, T.M., Richardson E.C., (2011): Living the Plan: Strategic Planning Aligned With Practice and Assessment, The Journal of Continuing Higher Education, 59 (1), 2-9 http://dx.doi.org/10.1080/07377363.2011.54975

Toma, J. D., (2010). Building Organizational Capacity: Strategic Management in Higher Education (I.Bask1). Baltimore: The Johns Hopkins University Press.

Ülgen, H. ve Mirze, S.K. (2010). Issletmelerde Stratejik Yönetim (Strategic Management in Business Enterprises) (5.Bask1). İstanbul: Beta Publications. 
Journal of Global Strategic Management | V. 7 | N. 1 | 2013-June | isma.info | 17-33 | DOI: 10.20460/JGSM.2013715673 Wissema, J.G. (2009). Üçüncü Kuşak Üniversitelere Doğru: Geçiş Döneminde Üniversiteleri Yönetmek (Towards the Third Generation Universities: Managing Universities in Transition)(Translated by. N.Devrim and T.Belge). İstanbul: Özyeğin University Publications. (Original study printing date:2006).

YÖK, (2007). Türkiye'nin Yükseköğretim Stratejisi (Higher Education Strategy of Turkey)(2007-1). Ankara: Meteksan A.Ş. 